\title{
Dissertações de mestrado defendidas no Programa de Pós-Graduação em Antropologia Social da UFPR - 2002 e 2003
}

Título: Honras \& Estratégias: diferentes formas de ser mulher no bairro das Flores

Autor: Simone Becker

Orientador: Miriam Furtado Hartung

Data da defesa: 02 de dezembro de 2002

Resumo: Esta pesquisa busca compreender o código de inserção e aceitação social (ou honra) dos moradores do Bairro das Flores-Periferia de Araucária, PR. Tal conhecimento é essencial para se entender quer as diferentes formas de ser mulhercasada, largada, solteira, viúva -, quer as estratégias por elas utilizadas para se deslocar entre essas categorias. Além de a honra feminina vincular-se à presença masculina, seja através do casamento, seja por meio da existência de uma memória de pertença vertical, ela também ancora-se no recato (ou comportamento omissivo/ passivo) das mulheres. A honra masculina, por sua vez, solidifica-se pela valentia e poder de conquista, ou ainda pela eficaz utilização de suas duas máquinas, a saber: o revólver ou outro utensílio de briga e o pênis. Per se a construção de ambas as honras é conflituosa, pois se, por um lado, o homem se reafirma pela proteção de sua mulher e pela conquista de outras, por outro, a mulher deseja ser possuída e possuir um homem-além de manter a memória de sua ascendência. Da infidelidade masculina, por exemplo, emergem estratégias femininas que possibilitam diferentes formas de convivência entre as mulheres, sempre temerosas frente à separação e à marginalização social. 
Título: O Dançarino Divino: um estudo antropológico sobre a dança clássica indiana

Autor: J oachim Andrade

Orientador: Sandra Stoll

Data da defesa: 14 de março de 2003

Resumo: Bharata Natyam, a forma mais popular da dança clássica Indiana, tem recebido reconhecimento universal como uma das expressões mais sutis da cultura indiana. Sua conexão íntima com o templo, como arte ritualística que espelha sentimentos imperceptíveis das devadasis, "dançarinas", reflete a tendência introspectiva da cultura hindu. Através de alguns dançarinos pioneiros e de uns poucos visionários dedicados no início do século XX, Bharata Natyam alcançou uma popularidade sem precedentes. Esta dança se realiza segundo os matízes mais delicados de uma peça, ou de um poema, por intermédio de um corpo, refletindo os princípios explicitados no tratado Natya Shastra. Nessa pesquisa esta dança é analisada numa perspectiva antropológica, do templo ao teatro, com as concessões que faz entre esses dois contextos. Para estes fins, na primeira parte dão-se as informações gerais sobre a dança indiana, referentes à sua origem, história e estilos clássicos diferentes. A segunda parte expõe análises da estrutura interna do repertório da Bharata Natyam. A parte final trata do modo de preservação e apropriação da dança por alguns de seus expoentes bem conhecidos bem como por dançarinos amadores da atualidade.

Título: A vida na Barra: uma etnografia de uma comunidade de pescadores do litoral norte do Paraná

Autor: Leticia de Paiva Rothen

Orientador: Edilene Coffaci de Lima

Data da defesa: 17 de março de 2003

Resumo: Neste trabalho o objetivo principal foi a elaboração de uma pequena etnografia de uma comunidade no litoral norte do Estado do Paraná, Barra do Superagui. Neste sentido, levanto aspectos característicos de seu "modo de vida", incluindo a atividade pesqueira, suas implicações e transformações ao longo do tempo; o crescente envolvimento da população com o turismo; a atuação na comunidade de ONGs ambientalistas - posto que a vila se localiza no entorno de um Parque Nacional - e a estrutura da vila e o modo como ela é pensada. A partir deste contexto, discuto questões relativas ao conceito de "população tradicional" (criticando uma postura teórica que analisa estas populações a partir de uma idéia de equilíbrio na sua relação com a natureza) e certas perspectivas que analisam as mudanças em comunidades como a estudada, tomadas como "tradicionais", a partir de uma ótica de "perda". 
Título: A 'comunidade da bênção': religião, família e trabalho na colônia Castrolanda

Autor: J oão Frederico Rickli

Orientador: Marcos Pazzanese Duarte Lanna

Data da defesa: 30 de julho de 2003

Resumo: Esta dissertação de mestrado é uma etnografia de Castrolanda, uma colônia fundada em 1951, em Castro - PR, por um grupo de imigrantes holandeses. A etnografia privilegia a descrição das atividades e da organização da Igreja Evangélica Reformada, a denominação calvinista à qual pertencem os membros da colônia, e da Cooperativa Castrolanda, que organiza a vida econômica do grupo, além da compreensão do modo como se constitui o parentesco na colônia. A articulação entre estas três esferas - a religião, o parentesco e o trabalho constitui o foco central deste trabalho, buscando compreender como, em Castrolanda, a igreja, articulada na linguagem do parentesco, constitui-se como a esfera dominante da vida comunitária, tornando-se o termo hierarquicamente englobante em relação às outras esferas da vida social do grupo. Nestes termos, existiria em Castrolanda uma peculiar articulação entre hierarquia e ética protestante, que está bem expressa no conceito local de 'comunidade da benção', que nomina esta dissertação.

Título: Tradição, mudança e o sentido da história entre os Kaiowá Guarani

Autor: Adriana Cristina Repelevicz de Albernaz

Orientador: Márnio Teixeira Pinto

Data da defesa: 04 de agosto de 2003

Resumo: Este trabalho traz a discussão sobre a chefia política entre os kaiowá Guarani (Reserva de Caarapó/MS) a partir de uma perspectiva histórica: confrontando a concepção de chefia tradicional, tal qual descrita por Pierre Clastres e outros autores, com às formas contemporâneas e tendo como pano de fundo os problemas sociais e a presença de Igrejas Cristãs e da Escola, que denotam mudanças nas suas formas tradicionais de viver. Sabendo que este grupo indígena organiza-se prioritariamente através da orientação religiosa e que resiste às formas de organização política centralizada, pergunta-se até que ponto as novas formas de chefia política podem ser consideradas como mudanças estruturais, através da reflexão sobre o que permanece e como permanece do que é tido como tradicional em política para os Kaiowá Guarani. 
Título: Os Mbyá e a natureza: um balanço bibliográfico

Autor: Valdirene Ganz

Orientador: Edilene Coffaci de Lima

Data da defesa: 18 de setembro de 2003

Resumo: $O$ eixo ao redor do qual gira a discussão desta pesquisa é a construção da pessoa Mbyá, visto que implica na inter-relação das séries animal, humana e divina. Tomo como referencial a literatura Tupi-Guarani, na medida em que esta oferece um modelo analítico para a reflexão da sociologia Mbyá e as discussões atuais desenvolvidas na Amazônia no que diz respeito a relação de outras populações indígenas com a natureza. Estão inter-conectados ao centro desta dissertação a característica fundamental que define a pessoa Mbyá, a mobilidade, e aspectos de suas representações sobre a natureza. Estas representações, por sua vez, influenciam na escolha dos lugares para esta sociedade constituir as suas aldeias.

Título: Wicca: paganismo urbano e religiosidade contemporânea

Autor: Alessandra Stremel Pesce Ribeiro

Orientador: Sandra Stoll

Data da defesa: 05 de dezembro de 2003

Resumo: A wicca é um fenômeno recente eainda pouco conhecido da literatura antropológica. Trata-se de um movimento de cunho religioso cujo o tema central consiste na celebração dos ciclos/processos naturais, como as mudanças das estações e os ciclos lunares. Seus praticantes se autodenominam bruxos, "pagãos" e/ou wiccanos e procuram desenvolver o contato com a natureza na sociedade contemporânea. Mas vivendo numa sociedade urbana e industrializada esse contato com a natureza não é facilmente obtido. Ao contrário, precisa ser recuperado, reaprendido e adaptado à realidade dos seus praticantes. Segundo esses, a proximidade com o mundo natural se faz por meio de um pensamento tido como "intuitivo", "mágico" e tipicamente "feminino"; padrões que diferem, e até mesmo se opõem, aos padrões vigentes na sociedade contemporânea. Essa última considerada "racional", "pragmática" e "masculina".

Título: Graffiti: uma etnografia dos atores da escrita urbana de Curitiba

Autor: Daniella Rosito Michelena Munhoz

Orientador: Selma Baptista

Data da defesa: 12 de dezembro de 2003

Resumo: Esta dissertação apresenta um panorama da escrita urbana de Curitiba, através da realização de uma etnografia dos escritores de grafite da cidade. Inicialmente expõe de que maneira uma manifestação global surge e se estabelece no espaço da cidade. Na seqüência, mostra como essa manifestação envolve os atores locais, permitindo que os jovens urbanos construam uma identidade vinculados a um referencial simbólico específico. Posteriormente, observa as repercussões que afetam as pessoas em geral. Finaliza com a visualização de como um fenômeno global se reproduz localmente e se virtualiza, realimentando o sistema de bens de consumo cultural que viabiliza sua existência. 